\title{
Citizen Reporters as a Hoax Prevention
}

\author{
Endah Imawati \\ Institute of Teacher Training and Education Widya Darma \\ Surabaya, Indonesia \\ endahimawati@ikipwidyadarma.ac.id
}

\author{
Setya Yuwana Sudikan \\ Universitas Negeri Surabaya \\ Surabaya, Indonesia \\ setyayuwana@unesa.ac.id
}

\begin{abstract}
The hate speech emerges in the digital media environment alongside of the freedom to speech. People has tendencies to write news articles without checking the accuracy of facts. The digital media manipulation to spread false news or hoaxes has an impact on the emergence of hostilities and the collapse of tolerance. This study aims to get the model of citizen journalism writing in digital media to overcome fake information. The research data is e-mails sent by Harian Surya readers to Citizen Reporter section from January to March 2018. A report writing must be transparent based on nine elements of journalism by Bill Kovach. The research result is media literacy development model to produce transparent reportages. The authors were also able to construct positive contents in reportage writing. Hence, that writing model is important to be developed so that public is accustomed to write reportage based on data, facts and events.
\end{abstract}

Keywords - writing; reportage; citizen reporter; media literacy; digital media.

\section{INTRODUCTION}

Media literacy is often paralleled to reading ability but not producing news articles. That assumption simplifies the development of media literacy capacity because media literacy is only considered as media illiteracy. The rapid progress of mass media should be followed by a media literacy movement. Thus, people can differentiate between the useful and useless media contents.

The purpose of media literacy is to give a greater control to the interpretation of media messages as the output of an interest construction. A media which has a purpose to stimulate the audience empowerment is also needed. It is related to the efforts to transcend the mere meaning of media literacy.

People are expected to be able to identify whether the information is right or wrong (hoax). The study of media literacy can be conducted by practicing media literacy model based on nine elements of journalism so that the information disseminated through mass media can be accounted for.

Education has a fundamental role to develop media literacy through activities that focus on socializing aspects of how to create news, how to access and select the useful programs which are suitable to the audiences' needs. Therefore, the selected programs can be their priorities in solving problems in everyday life. On the other hand, a challenging problem emerges as the rapid information flow shown in media nowadays. It makes the public gets confused to select and use the acquired information in more positive ways. If the public can produce news articles or event reportages that follow journalistic principles, so it is expected they will apply the skills when they share the information to any media platforms

The enhancement of media literacy skills is being a relevant need to do in order to develop the empowerment of digital media users. They have high media literacy skills, not only aware of communication etiquettes but also have constructive acts of receiving, producing and circulating the information contents (news).

Through this developed literacy and educational model, information from any corners of the worlds, in any kind of dynamics, are no longer consumed immediately, otherwise it will pass through a filtration or filter [1]. The first filter begins when the information owner produces news. The principles of journalism is used in the news will filter out the interests that may the receiver of the information be misunderstood.

A prudent attitude towards the information production which circulates on the media can bring a sense of peace, security and safety in society is an important moral message for developing public media literacy in Indonesia which has a diverse society. The public should verify the information first, whether it is right or wrong, before sharing it on the media platform. If it is wrong, especially containing defamations or triggering violence, then the information should not be shared. If the source is not clear, unverified, unreasonable and unbeneficial, then there is no need to spread it. On the other hand, the mainstream mass media, including online news media, is always expected to promote competence and independence although it has an affiliation to certain political or economic interests.

That citizen journalism as linguistically and communicatively bounded practices, can contribute to the public sphere where the general public may engage in public discussions, thereby working towards common goals and interests [2]. If the public access to information is large and the empowerment of civil society to observe works, especially when the media participates to cover an issue, the bargaining power of civil society to participate in correcting the policy will increase. The media may be traded, the ownership changes from one to another, but the newsroom should be led by a competent and morally right person to serve the public at large. The media literacy movement offers solutions in order to face the development of news media, including digital media, to form a balance, especially in maintaining harmony in society.

Citizen reportage becomes a new community that provides information actively through mass media, on printed media, radio, television and digital. The development of citizen reportage helps the mass media in supplying information that may have slipped under the monitoring activities by journalists. 
According to a survey conducted by students of the Polytechnic University in Singapore on a sample of 801 young people aged between 15 and 35 years, it was found that $80 \%$ of them believe that the traditional media is still seen as more credible than the Citizen Journalism. The young people confirmed that they could not trust the information that comes through social networks and are keen to verify if it comes from reliable sources [3]. Citizens who write on the Internet, blogs or social media are not called journalists directly. Ordinary citizens cannot be called simply journalists because they write or report the events they see and experience in print media, radio, television or digital media. There is a Code of Ethics of Indonesian Journalists issued by the Press Council which journalists must adhere.

That is the reason why they are called as citizen reporters, not citizen journalism. As the citizens who proclaim information, they just have to obey the daily life ethics. Those are having good and bad morals.

Creating media literacy can be done in various ways. To deal with the digital native generation whom always holds a digital technology on their hands, new media literacy strategies are needed. One of the strategies is providing a special space for young digital generation to write some information using proper journalistic ways based on the principles of journalism.

Although they are included in non-journalists citizen, the young digital generation may use the principles of journalism as a form of responsibility to the information that being shared. The nine principles of journalism by Bill Kovach and Tom Rosenstiel [4] suggests rules to be obeyed by journalists. However, seeing the technology development, Kovach added an element related to citizen reporters. The nine elements are as follows:

(1) The first obligation of journalism is to the truth. The form of "journalistic truth" to be achieved is not only accuracy, but also a practical and functional truth. It is a process of sorting-out that develops between the initial story and the interaction between the public, news sources and journalists within a certain time. The first principle of journalism - the pursuit of truth, without any particular interest (disinterested pursuit of truth) - is the most distinguishing between other forms of communication.

(2) The first loyalty of journalism is to the citizens. The loyalty to the citizens is the meaning of journalistic independence. Independence is free of all obligations, except loyalty to the public interest.

(3) The discipline of verification. What distinguishes between journalism and entertainment, propaganda, fiction, or art is the discipline of verification. Journalism focus on what is going on, just the way it is. The discipline of verification is used in journalistic activities such as searching for the events witnesses, making wider news sources networks, and asking comments from many parties.

(4) Journalists must maintain independent from those they cover. Their credibility lies on the dedication to accuracy, verification, greater public interest, and a desire to present information.

(5) It must serve as an independent monitor of power. They observe and encourage the leaders to avoid doing bad things, things that do not allow them to do as public officials or public affairs managers.

(6) Journalism should provide a forum for public criticism and compromise. Whatever media platforms are used, journalism should create forums to remind public about the important issues so that they make assessments and take actions.

(7) Journalism must strive to make the significant, interesting, and relevant news to be read, heard or watched.

(8) Journalists have an obligation to keep their comprehensiveness in proportion. Proportion and comprehensiveness are keys to the accuracy in better understanding of various ideas of the news.

(9) Journalists have an obligation to exercise their personal conscience. Everyone must have a sense of morality and personal responsibility or moral guide.

The nine elements can be adapted by citizens who write the news. Kovach added the 10th element after witnessing many citizens who became citizen reporters. This new element comes with the development of information technology, especially the Internet. The 10th element is that citizen has rights and responsibility in matters related to the news. Citizens are no longer passive consumers of the media, but they also create their own media. It is seen from the emerging of blogs, online journalism, citizen reporter, community journalism, and alternative media. Citizens can contribute their thoughts, opinions, news, etc., and thus also encourage the development of journalism.

The purpose of this research is to create a writing model for citizen reportage as an effort to disseminate media literacy. Based on the writing model for citizen reporters, it is expected that citizens who will share information can verify the facts to maintain the accuracy of the news.

\section{METHOD}

This study applied qualitative method to explain the phenomenon in depth description by using data collection. The qualitative method used in this research is intrinsic case study. The researcher explored and had deep understanding the most programs, events, activities, and processes. The data research is e-mails (contains of news articles) sent by readers of Harian Surya to Citizen Reporter section from January to March 2018. The reportages they produced must be transparent based on the use of nine elements of journalism by Bill Kovach.

\section{RESULT AND DISCUSSION}

The functions of the mass media is to inform, educate, influence, and entertain. In the paradigm of constructivism, the information or news submitted to the community is produced through the construction of reality process by the editorial meeting.

Mass media becomes one of the informers to the public. As technology has progressed rapidly, people can also share information through digital media. That change has made the mass media is no longer the only informant.

The public can share information easily. Those freedom and easiness have made many citizens are able to share the news quickly. However, the information that has been shared is not always accurate. 
The communication medium has a tremendous influence on the change of human civilization as the media users with different spatial concepts but can be reconciled through a tool called media as a medium to communicate the message [5]. In the virtual space, the use of technology medium has also changed the pattern of communication behavior in society. Although in virtual space, the real conditions of a social system based on social interaction, social stratification, culture, social institutions, power remain in force, including the possibility of a criminal system.

One of the government efforts to reduce hoaxes spreading is by blocking the Internet sites (websites) considered as a source of false information. Relating to the policy of websites blocking, the government has confirmed that the main consideration in taking the decision to block certain sites is the contents of the relevant website [6].

The government made a collaboration with the Press Councils to emphasize the mass media companies in Indonesia to be verified in order to confirm that those press companies have upheld democracy, justice, public interest, and professionalism in carrying out its functions. Media verification is expected to increase the professionalism of media companies, maintain a balanced and fair coverage and reduce the tendentious news and in turn reduce the hoax spreading.

That is the reason why media literacy is needed for the community. One of the reasons is to encourage the mainstream media to provide a special column for citizen reporter. Thus, not only the information can be disseminated quickly to the audience, mass media can also urge the public to understand media literacy. Citizens who will provide information are required to comply with the reporting elements as journalists do as the defenders of the information accuracy.

Harian Surya which is published in East Java has a special page called Citizen Reporter for people who want to write news or share some information. In addition, to print media, Citizen Reporter is also available in digital media version of Harian Surya, www.surabaya.tribunnews.com.

As a preliminary data, from 450 e-mails filtered by the editors, most citizens who write news article do not put on the news sources statements and specify the date. Those two factors make the information categorized as a lack of data accuracy. Hence, the information revision mechanism provided by Harian Surya with a citizen reporter writing training program through digital media.

The writing training through digital media took place during the study period, from February to March 2018. Most feedbacks given by the authors were positive. They understood that in order to make the news more transparent and balanced, there are nine elements of journalism should be a concern.

This may be due to technology progress which has its negative effects on students' skills of writing because of the availability of ready-made assignments. Moreover, teachers have adopted the beliefs that writing is a kind of communication; this has led them to focus on the subject itself and overlook the incorrect style of writing. Feeling that students have no inclination in writing due to their weakness in it has been the impetus for the researcher to do the current study. [7]. The absence of control of the fundamental issues in journalism practices contributes to the data and information that eventually collected and spread in social media.

The news actuality becomes the main value that influences the judgment in the production process of journalistic work. The actuality and speed are made possible by the digital media primarily because of its wide range of power which enables quick interaction within a short time.

Report writing skills can be taught even more effectively if teachers while educating these classes exploit authentic material through different activities. The students learn a great deal from activities derived from authentic materials, as they are real events going on in the world. They generate interests easily in students as taken from newspapers, magazines, and Internet which is modern media resources. The students learning report writing skills can be taught also to use authentic material for arranging diverse activities. [8]. The perspective of mass media is influenced by various aspects. They edit and narrate to determine a story title by accentuating certain aspects as well as ignoring other aspects. In this case, the media becomes a bridge between the community and the world.

Writing, regarded as the last, but not the least, of the four language macro skills acquired by learners, is generally regarded to be the most difficult skill among the four skills of language; and it is the skill which receives little, if any, treatment in language learning classes although its importance for academic work in higher education and academia is highly acknowledged by researchers in the field [9].

Reference [10] mentions that there are seven skills or abilities needed to achieve critical awareness in using media through media literacy, namely (1) analytical skills that require people to parse messages that they received into meaningful elements; (2) evaluating the meaning of those elements; (3) grouping is to determine the elements that have similarities and different elements to be grouped into different categories; (4) conclusions drawing based on the groupings and then generalize the element patterns into a wider message; (5) using general principles to describe something specifically; (6) collecting those elements into a new structure; and (7) abstracting to create a brief, clear and accurate description to explain the essence of the message shorter than the original message.

The mass media provides information about important events that are occurring or have occurred routinely. The differences that occur in the mass media is not something which done unintentionally and without purposes. The difference in the presentation, also known as media framing, is something that has been approved by those media themselves. Many things affect the news presentation in the mass media to the community.

Journalists as the first person in the production of news certainly has a role in influencing the news content. Besides reporters, it turns out there are also more entitled parties in determining the contents of the news and choose what should, may or should not be published in the news article. They are the ranks of the editor and of course the capital owners who have full power over the media [11].

The information publishing process on Citizen Reporter section in Harian Surya has the same procedure as news 
articles sent by journalists to the editors. It is the editor who manages and selects the information content sent by the citizens.

The efforts to socialize media literacy is important by considering the existence of Law No. 11 of 2008 on Electronic Information and Transactions (ITE Law). In the ITE Law, an act to disseminate false news (hoax) is regulated in Article 28 paragraph (1), which states every person who intentionally and without right to spread false and misleading news resulting in consumer losses in electronic transactions. The criminal threat of the article is mentioned in Article 45 paragraph (2) of the ITE Law which is 6 (six) years in prison and or a fine of not more than 1 billion rupiahs [12].

Today, the Internet is considered as a channel that offers almost unlimited democratic freedom. The Internet is used to track information, to correspond with thousands of other individuals, and to spontaneously form virtual communities that cannot possibly be shaped by traditional means [13]. That is why the virtual world (in this case digital media) is considered the best container in voicing opinions and expressions.

Digital media users hold control over the production and distribution of information. They can select the information to be obtained and the source of information selected. It also means that they can create information and pass it on.

The phenomenon of freedom to make and distribute information in digital media causes free control of the scattered information contents. It triggers the emergence of false news or often referred to as hoaxes and hate speech. The data, collected by the Ministry of Communications and Informatics, said there are as many as 800.000 sites in Indonesia indicates false news and hate speech spreading.

The pattern of communication and society's order changed with the development of Internet technology. It becomes a new place for people to speak their opinions and expressions [14]. This freedom of expression is reinforced by the legislation that states that everyone is free to argue and it is a fundamental human right. Digital media actors also assume that the Internet is a channel that allows them to have almost unlimited democratic freedom.

In subsequent developments, the freedom of speech was to have a negative impact. Some digital media users use it to make the false news. In accordance with the legislation and regulations made by the government in disseminating ITE information, it is expected that the rights of freedom of expressions for all people is protected by the government, but the public must also be wise and responsible in writing and delivering something in cyberspace.

That is why the society role is needed to prevent the hoaxes spreading. With the movement of media literacy, it is hoped that citizens can make the news true and transparent.

This study shows the role of students who become the main suppliers of reportage in Citizen Reporter section. Those who have obtained material on news writing with the principles of journalism and perform verification will share the information to the community.

The editor is not only in charge of arranging the order of sentences, diction use, proper use of punctuation, but also keeps the accuracy of the news. Although citizen reporters are not journalists, they can use the working ethics of journalists to keep reportage conducted according to the principles of journalism.

\section{CONCLUSION}

News writing in Citizen Reporter section on Harian Surya can be a media literacy development model. Discussions and workshops about news writing which concerned about data accuracy and hoax avoidance can be managed vastly through digital media. The writers' responses can be obtained quickly so that the media literacy skills applied easily. Everybody can write some information, but the writing process must be applied based on journalism elements to maintain the data accuracy. The procedure in verifying facts before publishing the news articles in Citizen Reporter section on Harian Surya minimizes the number of news writing errors.

\section{ACKNOWLEDGEMENT}

The author would like to thank to the Editors of Harian Surya for their openness during this research. As a major media in East Java, Harian Surya has given a model of media literacy development and wide opportunity to the public to write news articles in accordance with the journalistic principles.

\section{REFERENCES}

[1] R. Firmansyah, "Web News Clarification to Minimize Hoax News Spreading". Journal of Informatics. Vol 4 (2). Sept. pp. 230-235, 2017.

[2] S. Nah \& D. S. Chung, "Communicative Action and Citizen Journalism: A Case Study of OhmyNews in South Korea". International Journal of Communication. Vol 10. pp 2297-2317, 2016.

[3] H. El Semary and M. Al Khaja, "The Credibility of Citizen Journalism and Traditional TV Journalism among Emirati Youth: Comparative Study". American International Journal of Contemporary Research. Vol. 3(11). November. pp. 53-62, 2013.

[4] B. Kovach and T. Rosenstiel, Nine Elements of Journalism. Pantau: Jakarta, 2006.

[5] V. Juliswara, "Developing a Distinguished Media Literacy Model in Analyzing False Information (Hoax) in Social Media". Journal of Sociology Thought. Vol 4 (2). August. pp. 142-16, 2017.

[6] K.H. Siswoko, "Government Policy Denying the Spread of False News or Hoax". Journal of Estuary of Social Sciences, Humanities, and Monday. Vol. 1 (1) April. pp. 13-19, 2017.

[7] I.M. Muslim, "Helping EFL Students Improve their Writing". International Journal of Humanities and Social Science. Vol. 4(2). January. pp. 105-112, 2004.

[8] S. Fatima, "Teaching Report Writing Skills through Communicative Activities". American International Journal of Contemporary Research. Vol. 2(2). February. pp. 104-109, 2012.

[9] M. Mirlohi, K. Saeed, and M. Roustaei, "The Effect of Instruction on Writing Performance of Intermediate EFL Persian Students". International Journal of Linguistics. Vol. 4(4). December. pp. 325-343, 2012. URL:http://dx.doi.org/10.5296/ijl.v4i4.2448 doi:10.5296/ijl.v4i4.2448

[10] J. Potter, Media Literacy, Fifth Edition. Los Angeles, London, New Delhi, Singapore, Washington DC: Sage Publication, 2011.

[11] A. Sobur, Media Text Analysis. Rosda Karya: Bandung, 2015.

[12] I. Pomounda, Legal Protection for Victims of Fraud through Electronic Media (A Biological Approach). Journal of Legal Science Opinion. Vol. 3 (4). pp. 1-9, 2015.

[13] D. Holmes, Theory of Media Communication, Technology, and Society. Yogyakarta: Pustaka Pelajar, 2012. 
[14] D.M. Herawati, "The Spread of Hoax and Hate Speech as the Representation of Freedom of Opinion". Promedia Journal. Vol. ii (2). PP. 138-155, 2016. 